\title{
TECHNOLOGICAL TESTS USING QUARTZITE RESIDUES AS COMPONENT OF CERAMIC MASS AT THE PORCELAIN STONEWARE PRODUCTION
}

\author{
M. M. SOUZA ${ }^{1,2^{*}}$ and F. A. COSTA ${ }^{2}$ \\ ${ }^{1}$ Federal Institute of Rio Grande do Norte (IFRN) \\ ${ }^{2}$ Federal University of Rio Grande do Norte (UFRN) \\ marcondes.mendes@ifrn.edu.br*
}

Article submitted in Februry/2015 and accepted in March/2015

DOI: 10.15628/holos.2015.2749

\section{ABSTRACT}

This work aims to evaluate through technological tests the use of quartzite residues as component at the the production of porcelain stoneware. Were collected five samples of quartzites called of green quartzite, black quartzite, pink quartzite, goldy quartzite, white quartzite. After, the raw materials were milled, passed by a sieve with a Mesh of 200\# (Mesh) and characterized by chemical analysis in fluorescence of $x$-rays and also analysis of the crystalline phases by diffraction of $x$-rays. The porcelain tiles mass is composed of five formulations containing $57 \%$ of feldspar, $37 \%$ of clay and $6 \%$ of residues of quartzite with different coloration. For the preparation of the specimens, it was used uniaxial pressing, which afterwards were synthesized at $1150^{\circ} \mathrm{C}$,
\end{abstract}

$1200^{\circ} \mathrm{C}$ and $1250^{\circ} \mathrm{C}$. After the sintering, the specimens were submit for tests of technological characterization like: water absorption, linear shrinkage, apparently porosity, density and flexural strain at three points. The results presented in the fluorescence of $x$-rays showed a high-content of iron oxide on black quartzite that is why it was discarded the utilization of it in porcelain stoneware. All quartzite formulations had low water absorption achieved when synthesized at $1200^{\circ} \mathrm{C}$, getting 0.1 to $0.36 \%$ without having gone through the atomization process. At the tests of flexural strain, all the quartzite had in acceptance limits, according to the European norm EN 100, overcoming $27 \mathrm{MPA}$ at $1200^{\circ} \mathrm{C}$.

KEYWORDS: Quartzite, residue, porcelain stoneware.

\section{ENSAIOS TECNOLÓGICOS UTILIZANDO RESÍDUOS DE QUARTZITOS COMO COMPONENTES DA MASSA CERÂMICA NA PRODUÇÃO DE GRÉS PORCELANATO}

\section{RESUMO}

Este trabalho objetiva avaliar através de ensaios tecnológicos o uso de resíduos de quartzitos como componentes da massa cerâmica de grés porcelanato. Foram coletadas cinco amostras de quartzitos denominadas de quartzito verde, quartzito preto, quartzito rosa, quartzito dourado, quartzito branco. Em seguida, as matérias-primas foram moídas, passadas em uma peneira com malha de 200 Mesh e caracterizadas por meio de análise química por fluorescência de raios- $X$ e análise de fases cristalinas por difração de raios-X. A massa cerâmica foi composta por cinco formulações contendo $57 \%$ de feldspato, $37 \%$ de argila e $6 \%$ de resíduos de quartzitos com colorações diferentes. Para a preparação dos corpos de prova usou-se a prensagem uniaxial, os quais em seguida foram sinterizados a $1150^{\circ} \mathrm{C}, 1200^{\circ} \mathrm{C}$ e $1250^{\circ} \mathrm{C}$. Após a sinterização, os corpos- de-prova foram submetidos a ensaios de caracterização tecnológica como: absorção de água, retração linear, porosidade aparente, massa específica aparente e resistência à flexão em três pontos. Os resultados apresentados na fluorescência de raios- $X$, mostraram um elevado teor de óxido de ferro no quartzito preto, por isso foi descartada a utilização do mesmo em grés porcelanato. Todas as formulações dos quartzitos obtiveram baixa absorção de água quando sinterizados a $1200{ }^{\circ} \mathrm{C}$, obtendo absorção de água entre 0,1 a 0,36 \% sem terem passado pelo processo de atomização. Nos ensaios de resistência à flexão todos os quartzitos encontram-se nos limites de aceitação, segunda a norma europeia EN 100, superando $27 \mathrm{MPa}$ na sinterização a $1200^{\circ} \mathrm{C}$.

PALAVRAS-CHAVE: Quartzito, resíduo, grés porcelanato. 


\section{INTRODUCTION}

A Brazilian company that produces ceramics for civil construction is becoming aware of the need to avoid waste, and promote recycling and residues recovery. This contributes positively to the environment, by reducing the negative environmental impact of its activities and the proper use of natural resources, providing solutions for achieving sustainable development, and at the same time, increasing the profitability of their business.

In mass composition for porcelain stoneware is required that the microstructural characteristics are satisfied and technological properties utilized in the ceramic coating industry. Regarding the use of these residues for porcelain stoneware production, the aspects are very positive, since its chemical and mineralogical composition present constituents found in the raw material from quartzite rocks as quartz and feldspar.

The quartzite is geologically classified as a metamorphic rock composed almost entirely of quartz grains. Its origin is related to metamorphic processes action developed mainly on sedimentary rocks, rich in quartz as sandstones and cherts (rocks rich in amorphous silica (ABIROCHAS, 2014). Quartzite is a granoblastic metamorphic rock mainly consisting of quartz, and formed by recrystallization of sandstone or flint by contact or regional metamorphism (MROLSD, 2013).

A ceramic mass must have required characteristics to enable the improvement of a ceramic product. The formulation for these product manufactures is a research associated with many tests until the development of the final product during processing, and to achieve the properties required (VIEIRA, 2001). In ceramics pieces manufacture is quite common to mix two or more materials to the mass composition (CASAGRANDE, 2008).

The main mineralized areas of quartzite in Paraíba/PB in Borborema Province, specifically in Junco do Seridó and Várzea cities (Figure 1), whose deposits extend to the cities of Equador and Ouro Branco, Rio Grande do Norte/RN, Brazil. An intense extraction of square or rectangular flagstones of quartzite are observed in these areas, serving for application in coating of walls, sidewalks, pools and in modern and rustic building floors.

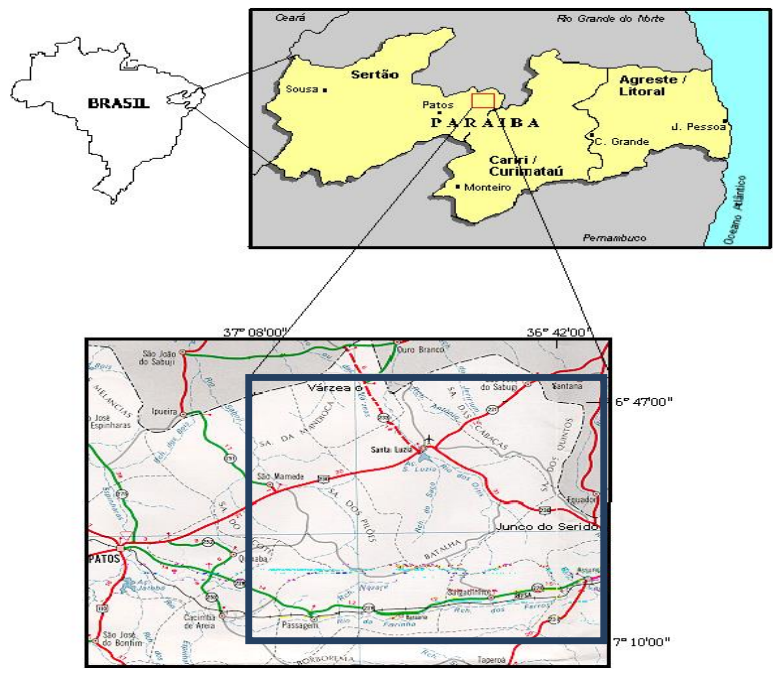

Figure 1: Location Map of Junco do Seridó and Várzea/PB Source: SOUZA et al, (2001). 
In sawmills, the quartzite plates are transformed into square or rectangular flagstone, standardized length and free widths, in order to provide its better use. Larger parings are sawed generating fillets. These are higher value-added products and are intended mostly for domestic market, and a small portion for foreign market (Figure 2).

(a)

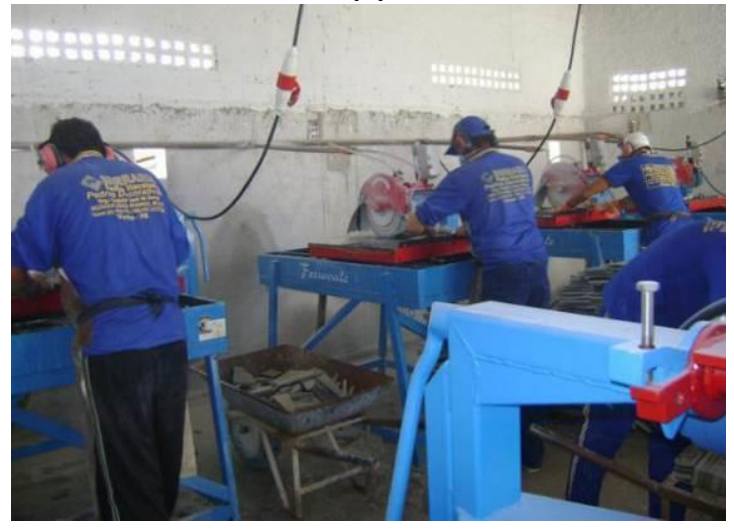

(b)

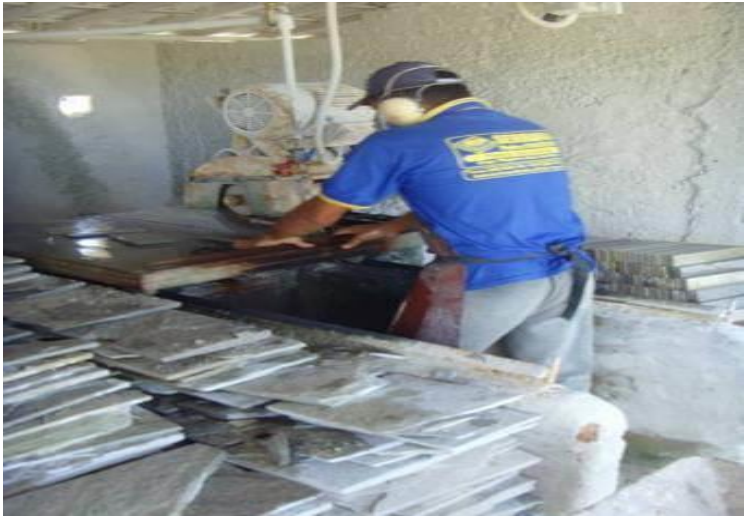

Figure 2: Processing of Quartzite in Itacolomy Sawmill in Várzea/PB

Facing the environmental impacts generated by quartzite production in Várzea city, there is the possibility of using the quartzite residues as filler material in white or porcelain tiles ceramic, in order to minimize the environmental damage, caused by the mining industry of the region. Data obtained from Itacolomy sawmill, indicates that the residues production generated from processing of quartzite is, on average, 30 to 40 wheelbarrow per day, with an average weight of $62.218 \mathrm{~kg}$ per car (see Table 01).

Table 01: Quartzite residues production

\begin{tabular}{|c|c|c|c|c|}
\hline \multicolumn{5}{|c|}{ Total per day } \\
\hline Wheelbarrow per day & $\begin{array}{c}\text { Average weight of 1 } \\
\text { wheelbarrow (Ton) }\end{array}$ & $\begin{array}{c}\text { Residues production } \\
\text { per day (Ton) }\end{array}$ & Density & Volume $\left(\mathrm{m}^{3}\right)$ \\
\hline 30 & 0.0621 & 1.863 & 2.56 & 0.727 \\
\hline 35 & 0.0621 & 2.173 & 2.56 & 0.848 \\
\hline 40 & 0.0621 & 2.484 & 2.56 & 0.970 \\
\hline
\end{tabular}

In order to create a formulation for porcelain stoneware, which gives advantage to quartzite residues in replacement of quartz; clay and potassium feldspar were introduced to this formulation, utilizing in white ceramic production, for study and comparison purposes.

\section{METHODOLOGY}

Clay, feldspar and quartzite residues were the raw materials utilized in this study. Clay is little plastic and has high mechanical strength. However, orthoclase feldspar samples were collected with a particle size of $\mathbf{2 0 0}$ mesh, both from Armil Mineração do Nordeste Ltda. Quartzite residues were collected after ore processing from Serraria Pedra Itacolmy Ltda. By the fact that they presented different colors probably due to some chemical or physical changes in the geological formation environment, a selection process was performed, after collection, in the ore storage patio with quartzite residues. The quartzites were identified by their coloring as: White Quartzite (QB), Golden Quartzite (QD), Black Quartzite (QP), Pink Quartzite (QR) and Green Quartzite (QV). 
The quartzite residues were crushed in mill of alumina balls, then, gone through a sieve with grid of 200 Mesh. As for feldspar and clay, they already have particle size less than 200 Mesh. Then, raw materials characterization analyzes were performed by chemical analysis per X-ray fluorescence and crystalline phase analysis per X-ray diffraction. The ceramic mass was composed of five formulations, with $57 \%$ of feldspar, $37 \%$ of clay and $6 \%$ of quartzite residues with different colors. The uniaxial pressing was utilized for samples preparation, and then sintered at $1150{ }^{\circ} \mathrm{C}$, $1200^{\circ} \mathrm{C}$ and $1250^{\circ} \mathrm{C}$. After sintering, the samples were submitted to technological characterization tests as water absorption, linear shrinkage, apparent porosity, apparent specific mass and bending strength at three points.

\section{RESULTS AND DISCUSSIONS}

\subsection{Characterization of raw materials}

\subsubsection{Chemical characterization (FRX)}

The chemical analysis results of quartzite, clay and feldspar obtained by FRX, are shown in Table 02. All quartzite have high contents of $\mathrm{SiO}_{2}$ (68.076 \%) and $\mathrm{Al}_{2} \mathrm{O}_{3}$ (17.224 \%), identifying aluminosilicate in materials composition. As it is a quartzite, the predominant compound is silica $\left(\mathrm{SiO}_{2}\right)$, showing the composition of a compound derived from quartz. $\mathrm{High} \mathrm{SiO}_{2}$ content indicates presence of silicates and free silica. The presence of free silica, correspondent to quartz and derivatives, provides a reduction in plasticity of the ceramic mass. In general, high content of $\mathrm{SiO}_{2}$ and $\mathrm{Al}_{2} \mathrm{O}_{3}$ indicates it is chemical composition of clay minerals as quartz, feldspar and mica group.

Table 02: Chemical analysis obtained by FRX of raw materials

\begin{tabular}{|c|c|c|c|c|c|c|c|}
\hline \multirow{2}{*}{$\begin{array}{l}\text { Oxides } \\
\text { Present }\end{array}$} & \multicolumn{7}{|c|}{ Concentration by Weight (\%) } \\
\hline & $\begin{array}{c}\text { White } \\
\text { quartzite }\end{array}$ & $\begin{array}{c}\text { Pink } \\
\text { quartzite }\end{array}$ & $\begin{array}{c}\text { Golden } \\
\text { Quartzite }\end{array}$ & $\begin{array}{c}\text { Black } \\
\text { Quartzite }\end{array}$ & $\begin{array}{c}\text { Green } \\
\text { Quartzite }\end{array}$ & Clay & Feldspar \\
\hline $\mathrm{SiO}_{2}$ & 68.076 & 91.801 & 88.268 & 55.485 & 81.948 & 64.072 & 57.412 \\
\hline $\mathrm{Al}_{2} \mathrm{O}_{3}$ & 17.224 & 6.004 & 7.956 & 18.888 & 12.183 & 23.925 & 18.030 \\
\hline $\mathrm{K}_{2} \mathrm{O}$ & 8.216 & 1.328 & 2.181 & 4.257 & 3.821 & 3.081 & 23.738 \\
\hline $\mathrm{Fe}_{2} \mathrm{O}_{3}$ & 2.990 & 0.456 & 0.947 & 11.210 & 1.346 & 4.884 & 0.371 \\
\hline $\mathrm{MgO}$ & 1.216 & - & - & 4.115 & - & 0.481 & - \\
\hline $\mathrm{CaO}$ & 0.902 & - & - & 3.725 & - & 0.156 & - \\
\hline $\mathrm{TiO}_{2}$ & 0.500 & 0.076 & 0.128 & 1.547 & 0.165 & 2.681 & - \\
\hline $\mathrm{BaO}$ & 0.472 & - & - & - & 0.091 & - & - \\
\hline $\mathrm{SO}_{3}$ & 0.261 & 0.283 & 0.411 & 0.211 & 0.341 & 0.388 & - \\
\hline $\mathrm{Rb}_{2} \mathrm{O}$ & 0.039 & 0.005 & 0.007 & 0.016 & 0.013 & 0.035 & 0.368 \\
\hline $\mathrm{ZrO}_{2}$ & 0.036 & 0.021 & 0.023 & 0.061 & 0.027 & 0.072 & - \\
\hline $\mathrm{MnO}$ & 0.031 & 0.026 & - & 0.154 & - & - & - \\
\hline $\mathrm{CuO}$ & 0.011 & - & - & - & 0.008 & 0.049 & - \\
\hline $\mathrm{SrO}$ & 0.010 & - & - & 0.083 & 0.005 & 0.097 & 0.045 \\
\hline $\mathrm{ZnO}$ & 0.008 & - & - & - & - & 0.019 & - \\
\hline $\mathrm{Y}_{2} \mathrm{O}_{3}$ & 0.007 & - & - & 0.010 & - & 0.017 & - \\
\hline $\mathrm{Sm}_{2} \mathrm{O}_{3}$ & - & - & 0.077 & - & 0.050 & - & - \\
\hline $\mathrm{P}_{2} \mathrm{O}_{5}$ & - & - & - & 0.202 & - & - & - \\
\hline $\mathrm{Cr}_{2} \mathrm{O}_{3}$ & - & - & - & 0.037 & - & - & - \\
\hline $\mathrm{Ir}_{2} \mathrm{O}_{3}$ & - & - & - & - & - & 0.045 & - \\
\hline$A C$ & - & - & - & - & - & - & 0.036 \\
\hline
\end{tabular}


The elements presented in quartzite compositions, in quantitative and qualitative terms, present accordance with the raw materials for porcelain stoneware production, whose majority elements are clay, feldspar, quartz, kaolin, etc. All quartzites have $\mathrm{SiO}_{2}$ and $\mathrm{Al}_{2} \mathrm{O}_{3}$ as major constituents. But the black quartzite showed a higher percentage of $\mathrm{Fe}_{2} \mathrm{O}_{3}(11.210 \%)$. The iron oxide $\left(\mathrm{Fe}_{2} \mathrm{O}_{3}\right)$, incorporated in the ceramic mass, reduces the plasticity, decreases the firing shrinkage and facilitates masses drying and allows the decrease of mechanical strength; however, by the little melting during sintering, it provides toughness to the ceramic sample, thereby prevents the utilization of black quartzite as a constituent element in the ceramic mass for porcelain stoneware. $\mathrm{Fe}_{2} \mathrm{O}_{3}$ concentrations ranging from $0.456 \%$ (Pink Quartzite) and $11.210 \%$ (Black Quartzite), however, the concentrations present in white, pink, golden and green quartzite are within acceptable values for the manufacturing of porcelain stoneware (BIFFI, 2002).

The $\mathrm{K}_{2} \mathrm{O}$ shown on the composition of all quartzite is derived from compound of feldspar $\left(\mathrm{K}_{2} \mathrm{O}\right)$. According to the literature (MORAES, 2007), this oxide has potential application in the production of porcelain tiles. This compound is considered as a melting and provides mechanical strength to ceramic samples when sintered between $950{ }^{\circ} \mathrm{C}$ to $1000{ }^{\circ} \mathrm{C} . \mathrm{MgO}, \mathrm{CaO}, \mathrm{BaO}$ and $\mathrm{SO}_{3}$ oxides are melting agents and decrease the refractoriness of the ceramic samples, i.e., contribute to CPs melting.

FRX result of clay in Table 02 shows the presence of $\mathrm{SiO}_{2}$ and $\mathrm{Al}_{2} \mathrm{O}_{3}$ as the main oxides with contents of 64.072 and 23.925, respectively. In the same table, FRX result analysis of feldspar shows the presence of $\mathrm{SiO}_{2}$ and $\mathrm{K}_{2} \mathrm{O}$ as the main oxides with contents of 57.412 and 23.738, respectively.

\subsubsection{Mineralogical characterization (DRX)}

DRX analysis performed with clay sample is shown in Figure 03. It is observed by X-ray diffraction, the peaks characteristic of crystalline phases related to the quartz $\left(\mathrm{SiO}_{2}\right)$, which is the mineral responsible for the development of plasticity in the ceramic mass conformation. It was also identified the presence of kaolinite $\left(\mathrm{Al}_{2}\left(\mathrm{Si}_{2} \mathrm{O}_{5}\right)(\mathrm{OH})_{4}\right)$ and illite $\left.\left(\mathrm{K}, \mathrm{H}_{3} \mathrm{O}\right) \mathrm{Al}_{2} \mathrm{Si}_{3} \mathrm{AlO}_{10}(\mathrm{OH})_{2}\right)$ showing the same composition elements identified in the results of $\mathrm{X}$-ray fluorescence (FRX).

The diffraction result of feldspar X-ray is shown in Figure 04. It was observed the presence of albite (NaAlSi3O8) and microcline (KAISi3O8), showing the same composition elements identified in the results of X-ray fluorescence (FRX).
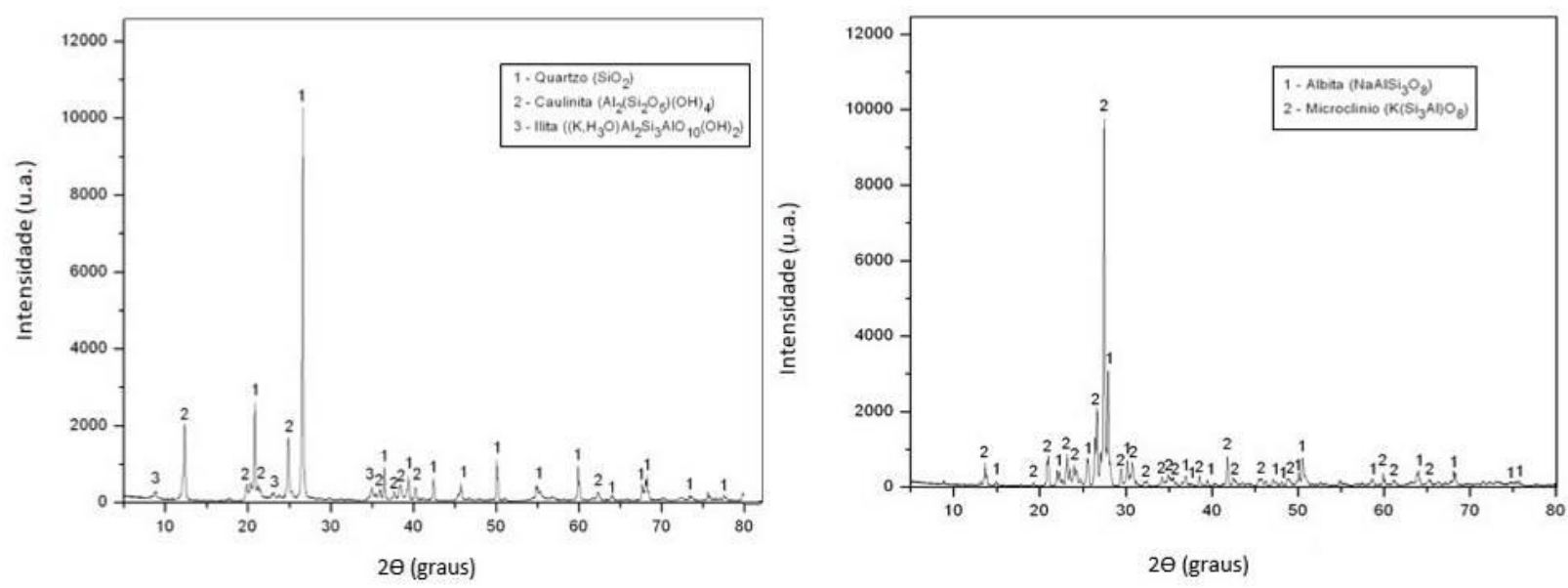

Figures 03 and 04 - Mineralogical analysis obtained by DRX of Clay and Feldspar 
The diffraction results of X-ray, shown in Figures 05 to 09, showed that the quartzite mineralogical composition is as follows: white quartzite is composed of quartz, muscovite and feldspar (microcline); the pink quartzite consists of quartz, muscovite and feldspar; the golden quartzite consists of quartz, muscovite and microcline; the black quartzite consists of quartz, biotite, albite and chlorite; the green quartzite is composed of quartz and muscovite. It is proven, therefore, with the diffraction analysis results of X-ray, that there is presence of quartz $\left(\mathrm{SiO}_{2}\right)$ in all quartzite.
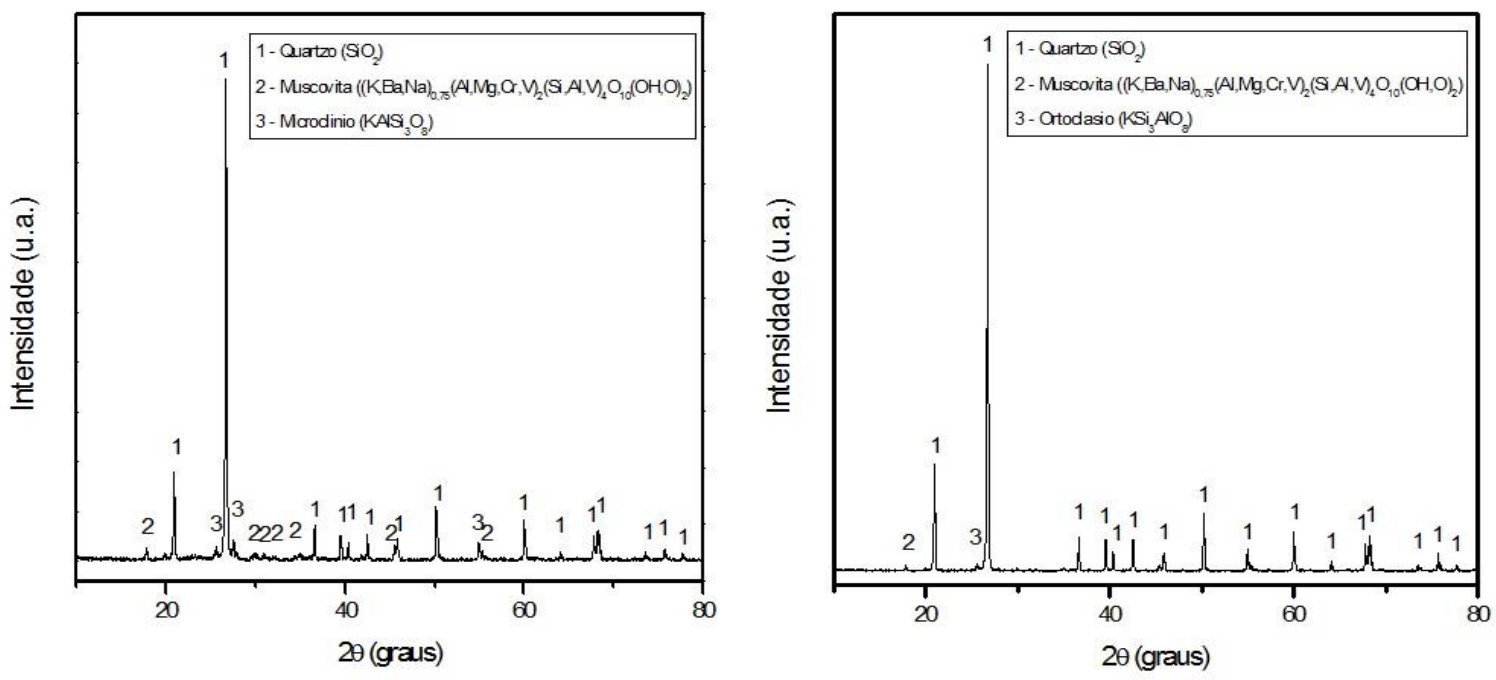

Figures 05 and 06 - Mineralogical analysis obtained by DRX of White Quartzite and Pink Quartzite
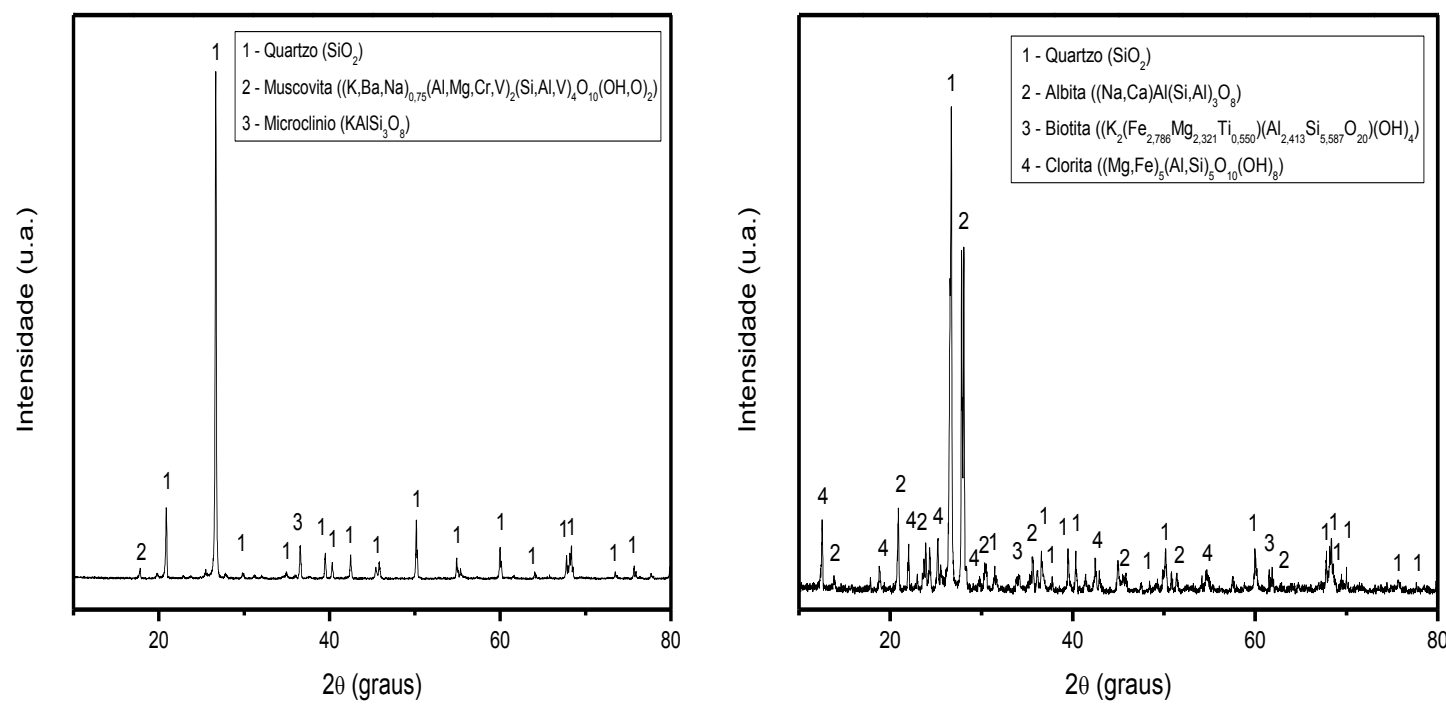

Figures 07 and 08 - Mineralogical analysis obtained by DRX of Golden Quartzite and Black Quartzite 


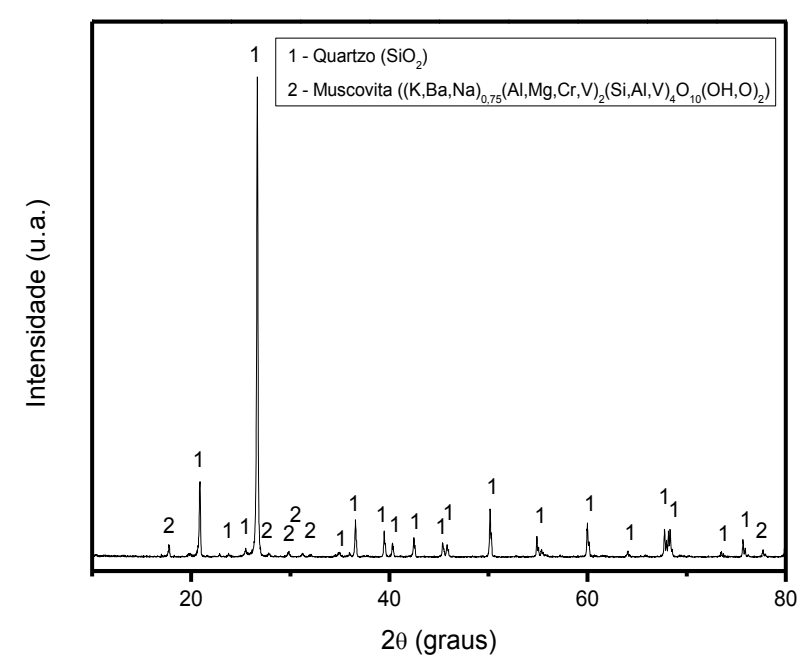

Figure 09 - Mineralogical analysis obtained by DRX of Green Quartzite

DRX analyzes, performed with each sample of quartzite, found diffraction peaks characteristic of crystalline phases related to quartz $\left(\mathrm{SiO}_{2}\right)$, which is the mineral responsible for reducing the plasticity and act as an inert during ceramic mass sintering. It was also observed the presence of muscovite mica $\left.(\mathrm{K}, \mathrm{Ba}, \mathrm{Na})_{0.75}(\mathrm{Al}, \mathrm{Mg}, \mathrm{V})_{2}(\mathrm{Si}, \mathrm{Al}, \mathrm{V})_{4} \mathrm{O}_{10}(\mathrm{OH}, \mathrm{O})_{2}\right)$, which is a mineral of lamellar texture and, in fine granulometry may act as a melting material due to the presence of alkaline oxides (microcline feldspar and orthoclase feldspar), who facilitates the formation of liquid phase, which is of large importance during sintering.

See next, the results obtained from technological tests applied to formulations with different tonalities and with quartzite residues.

\subsubsection{Linear firing shrinkage}

Figure 10 shows the results of linear shrinkage of fired samples at $1150{ }^{\circ} \mathrm{C}, 1200{ }^{\circ} \mathrm{C}$ and $1250^{\circ} \mathrm{C}$.

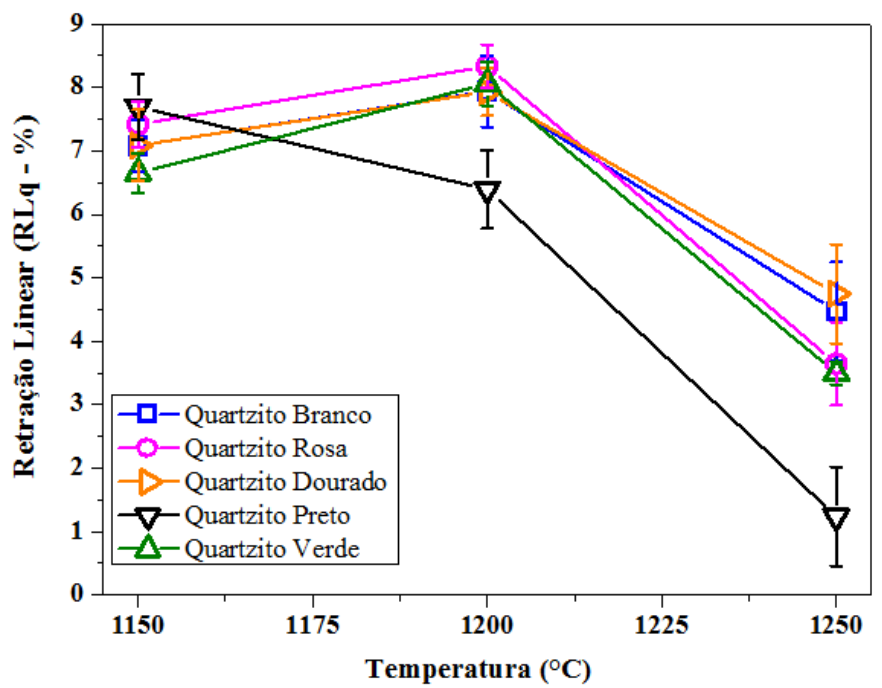

Figure 10: Linear firing shrinkage (RLq) of White, Pink, Golden, Black and Green Quartzite sintered at $1150{ }^{\circ} \mathrm{C}, 1200$ ${ }^{\circ} \mathrm{C}$ and $1250{ }^{\circ} \mathrm{C}$. 
According to the results shown in the graph, there was an increase in the linear shrinkage of the samples with the increase of the temperature from $1150{ }^{\circ} \mathrm{C}$ to $1200{ }^{\circ} \mathrm{C}$ of all formulations with quartzite, except for formulations with black quartzite (reduction of $16.86 \%$ ). The linear shrinkage of black quartzite was lower than the others due to the presence of melting oxides as $\mathrm{Fe}_{2} \mathrm{O}_{3}(11.21 \%), \mathrm{MgO}(4.115 \%), \mathrm{CaO}(3.725 \%)$ and $\mathrm{K}_{2} \mathrm{O}$ (4.257 \%), i.e., materials which decrease the melting point of the ceramic masses (refractoriness), as well as the linear shrinkage and formation of liquid phases.

It is observed that the ceramic mass prepared with white, pink, golden and green quartzite showed higher linear shrinkage when the sintering temperature increased from $1150{ }^{\circ} \mathrm{C}$ to 1200 ${ }^{\circ} \mathrm{C}$, showing the strong influence of temperature on the linear shrinkage of the samples, which behavior is attributed to the loss of samples mass, and to the post reactivity of high sinterability of the formulations, besides the formation of liquid phases and concentration of incorporated quartzite.

All quartzite formulations show lower linear shrinkage with the increase of sintering temperature to $1250{ }^{\circ} \mathrm{C}$. This reduction of linear shrinkage may be related to reduction reactions that occur during sintering, causing samples expansion due to gas trapping, released from inside the samples during reactions, being detrimental to mechanical strength and water absorption of the material. The quartzite incorporated into the ceramic mass act as "skeleton" former of the ceramic sample in the sintering process, by providing the liquid phase and filling the pores of the ceramic body, influencing thereby, on porosity and mechanical strength of the ceramic.

As may be observed, the white and golden quartzite formulations had suffered less retraction in the sintering at $1250{ }^{\circ} \mathrm{C}$. It is believed that this occurred because both mixtures contain the same mineral, i.e., quartz, microcline and muscovite.

\subsubsection{Water absorption}

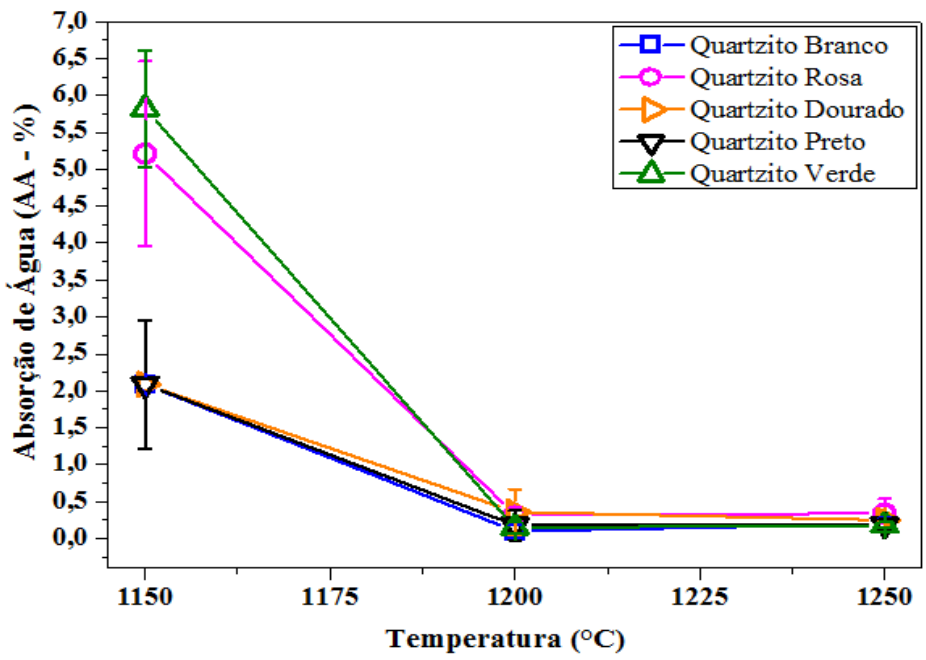

Figure 11: Shows the results of water absorption (AA) of quartzite formulations sintered at $1150{ }^{\circ} \mathrm{C}, 1200{ }^{\circ} \mathrm{C}$ and $1250^{\circ} \mathrm{C}$.

One of the main characteristics of porcelain stoneware is the low water absorption ( $<0.5 \%$ ). The samples sintered at $1150^{\circ} \mathrm{C}$ showed AA between 2.09 and $5.82 \%$, being this behavior attributed to the large amount of samples pores, from the compression process and the sintering 
temperature, responsible for closing and partial rounding of pores, due to the diffusion of the material.

The quartzite formulations showed a reduction in water absorption at sintering temperature of $1200^{\circ} \mathrm{C}$, with AA ranging from $0.1 \%$ to $0.36 \%$. It is believed that this occurred due to the presence of melting material which, during sintering at $1200^{\circ} \mathrm{C}$, melted and filled the pores, closed and partially rounded them, absorbing less water. The presence of high melting content in quartzite compositions increased the amount of liquid phase during sintering, promoting a higher densification.

The samples of quartzite sintered at $1250^{\circ} \mathrm{C}$ showed lower water absorption, which ranged from $0.18 \%$ to $0.33 \%$. Similarly to what occurred at a temperature of $1200^{\circ} \mathrm{C}$, there was a decrease in water absorption due to the presence of melting material which, during sintering at $1250^{\circ} \mathrm{C}$, the samples melted and filled pores, they partially closed and rounded, absorbing less water.

According to ceramic classification for coatings (ANFACER, 2002), the samples of quartzite sintered at $1150{ }^{\circ} \mathrm{C}$ are classified as semi-stoneware product - Group Ila (AA between 3\% and 6\%); as for quartzite sintered at $1200^{\circ} \mathrm{C}$ are classified as porcelain stoneware product - Group la (AA < $0.5 \%)$, as well as quartzite sintered at $1250{ }^{\circ} \mathrm{C}$, which are classified as product of porcelain stoneware - Group la (AA < $0.5 \%$ ), except for pink quartzite which presented an AA of $3.34 \%$ (semistoneware - Group Ila).

\subsubsection{Apparent porosity}

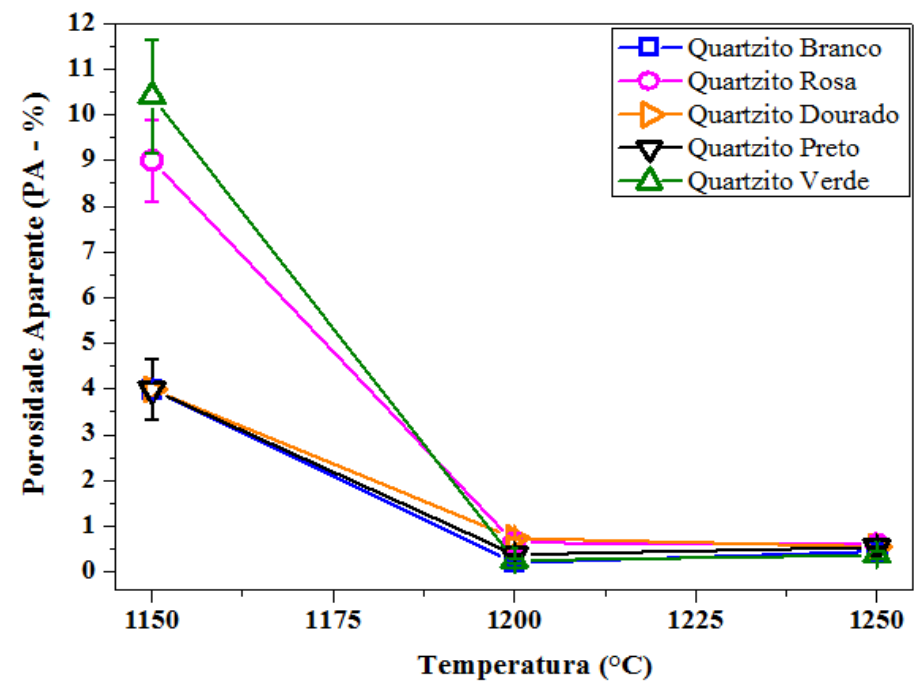

Figure 12: Apparent porosity (PA) of White, Pink, Golden, Black and Green Quartzite sintered at $1150{ }^{\circ} \mathrm{C}, 1200{ }^{\circ} \mathrm{C}$ and $1250^{\circ} \mathrm{C}$.

Figure 12 shows the apparent porosity result of quartzite sintered at $1150{ }^{\circ} \mathrm{C}, 1200{ }^{\circ} \mathrm{C}$ and $1250{ }^{\circ} \mathrm{C}$. The quartzite formulations sintered at $1150^{\circ} \mathrm{C}$ showed apparent porosity between $3.99 \%$ and $10.40 \%$, indicating higher percentages of porosity to pink quartzite formulations (9.0\%), and green (10.4\%) due to silica and hematite content, respectively.

The samples sintered at $1200{ }^{\circ} \mathrm{C}$ showed homogeneity of apparent porosity values, corroborating with water absorption results. The sintered samples PA varied between $0.2 \%$ and $0.74 \%$, being consistent with AA results. It is observed that the lower apparent porosity, lower is the water absorption of these ceramic samples. All formulations of white, golden, pink, black and 
green quartzite, sintered at $1250{ }^{\circ} \mathrm{C}$ showed uniformity in apparent porosity values due to the presence of the liquid phase during sintering, promoting large densification and pores filling, reducing, thus, the porosity.

It is observed that there is a variation relatively low of apparent porosity between the formulations for each sintering temperature. It is observed that the same formulations showing higher and lowest apparent porosity, for each sintering temperature, are the same which presented higher and lower water absorption. The apparent porosity reduction may be understood by the large amount of glassy phase, which penetrates into the pores while liquid, during sintering.

\subsubsection{Apparent specific mass}

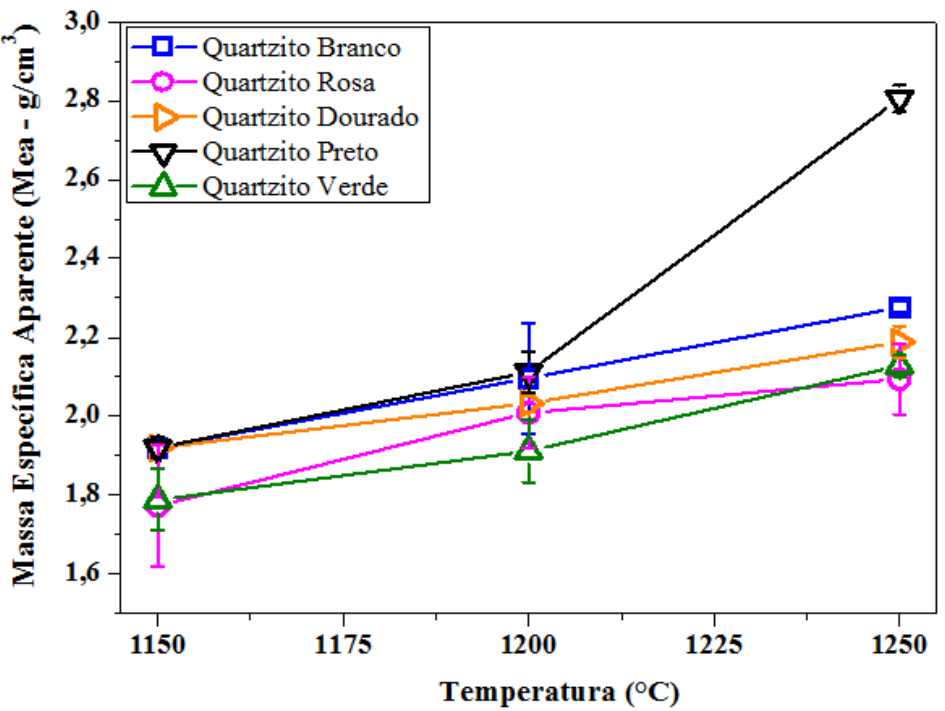

Figure 13: Apparent specific mass (MEA ) of White, Pink, Golden, Black and Green Quartzite sintered at $1150^{\circ} \mathrm{C}$, $1200^{\circ} \mathrm{C}$ and $1250^{\circ} \mathrm{C}$.

Figure 13 consist of the apparent specific mass results (MEA) of quartzite formulations sintered at $1150^{\circ} \mathrm{C}, 1200^{\circ} \mathrm{C}$ and $1250{ }^{\circ} \mathrm{C}$. It is observed that an increase of apparent specific mass occurred in all quartzite formulations samples with the increase of the temperature. Samples sintered at $1150{ }^{\circ} \mathrm{C}$ have the specific mass ranging between $1.733 \mathrm{~g} / \mathrm{cm} 3$ and $1.92 \mathrm{~g} / \mathrm{cm} 3$. As for ceramic samples sintered at $1200{ }^{\circ} \mathrm{C}$ showed variation in specific mass around $1.912 \mathrm{~g} / \mathrm{cm} 3$ and $2.112 \mathrm{~g} / \mathrm{cm} 3$, and samples sintered at $1250{ }^{\circ} \mathrm{C}$ ranging between $2.094 \mathrm{~g} / \mathrm{cm} 3$ and $2.805 \mathrm{~g} / \mathrm{cm} 3$. The results are consistent with the literature and showed densification behavior of samples with increasing sintering temperature. The higher the sintering temperature, the higher the amount of glassy phase, penetrating and filling the pores while in liquid phase, during sintering, thus, the ceramic samples have higher density;

In the sintering process occurs diffusion in the solid form and liquid phase formation, thus there is a filling of the pores. The higher the closing of the pores, the higher will be the apparent specific mass of the material. The sintering temperature strongly influences the ceramic samples densification, as well as its mechanical strength.

It is observed that in sintering at $1250^{\circ} \mathrm{C}$, the formulations had higher values of MEA $(2.094$ $\mathrm{g} / \mathrm{cm} 3$ to $2.805 \mathrm{~g} / \mathrm{cm}^{3}$ ), probably due to the large concentration of melting materials, which densify the sample when in liquid form, removing the existing pores by capillarity strength. Thus, 
the formulations of white, golden and black quartzite, when sintered at $1250{ }^{\circ} \mathrm{C}$, are presented according to the European Standard EN 87, which requires that the apparent specific mass is larger than $2.20 \mathrm{~g} / \mathrm{cm} 3$, to porcelain stoneware.

\subsubsection{Tensile strength to three points bending}

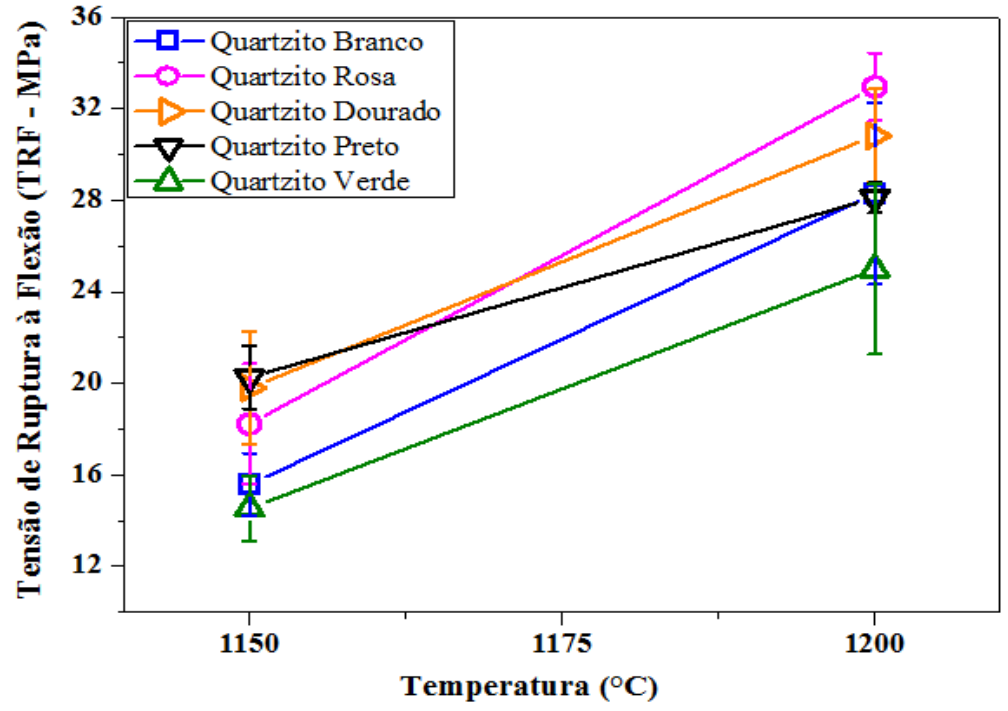

Figure 14: Tensile Strength to Bending (TRF) of White, Pink, Golden, Black and Green Quartzite sintered at $1150{ }^{\circ} \mathrm{C}$ and $1200^{\circ} \mathrm{C}$.

Figure 14 shows the results of tensile strength to three points bending of quartzite samples at $1150{ }^{\circ} \mathrm{C}$ and $1200{ }^{\circ} \mathrm{C}$. The quartzite samples sintered at $1250^{\circ} \mathrm{C}$ were discarded due to the unavailability to perform this analysis because they melted. All quartzite formulations showed a substantial increase in mechanical strength to bending with the increase of sintering temperature from $1150{ }^{\circ} \mathrm{C}$ to $1200^{\circ} \mathrm{C}$.

It is observed that the rupture tensile to bending increased, according to the increase of the maximum sintering temperature, as linear shrinkage and apparent specific mass properties. The quartzite samples sintered at $1150^{\circ} \mathrm{C}$ showed mechanical strength to bending from $14.54 \mathrm{MPa}$ to $20.25 \mathrm{MPa}$, black quartzite (20.25 MPa) and golden quartzite (19. $80 \mathrm{MPa}$ ) samples were the most resistant to bending. As for formulations sintered at $1200{ }^{\circ} \mathrm{C}$ showed values of mechanical strength to bending between $22.93 \mathrm{MPa}$ and $31.23 \mathrm{MPa}$, with pink quartzite (31.23 $\mathrm{MPa}$ ) and golden quartzite (30.82 $\mathrm{MPa}$ ) showing the higher values.

It is noteworthy that ABNT does not classify coatings as resistance to bending, although mention how to test. However, the European standard UNI EN 100 makes reference to the average value which must present the upper TRF at $27 \mathrm{MPa}$, for a pressed coating, and with AA less than $0.5 \%$. According to this information, it is observed that samples of white, pink, golden and black quartzite formulations reached the average value of strength to bending, with $28.28 \mathrm{MPa} ; 31.23$ $\mathrm{MPa} ; 30.82 \mathrm{MPa}$ and $28.11 \mathrm{MPa}$ at $1200{ }^{\circ} \mathrm{C}$ sintering, except for the green quartzite formulation, $22.93 \mathrm{MPa}$.

\section{CONCLUSIONS}

This research, using quartzite residues as component of ceramic mass for porcelain stoneware production, concludes that: 
1. The chemical analysis by x-rays fluorescence of quartzite residues demonstrates the presence of silica as the major oxide, especially for analysis of black quartzite which showed a high iron content. Therefore, its use in porcelain stoneware was discarded due aesthetic and structural issue, owing to its melting at $1250^{\circ} \mathrm{C}$.

2. The results showed that the quartzite residue may be utilized at a percentage of $6 \%$, added in the ceramic mass with $57 \%$ of feldspar and $37 \%$ of clay at $1200{ }^{\circ} \mathrm{C}$, which showed the best results in sintered samples.

3. It appears that there is a relatively high variation in water absorption and linear shrinkage between formulations, for sintering temperature at $1150{ }^{\circ} \mathrm{C}$, being more uniform at $1200{ }^{\circ} \mathrm{C}$ and $1250{ }^{\circ} \mathrm{C}$, except for black and pink quartzite, at respective temperatures.

4. All quartzite formulations had low water absorption when sintered at $1200{ }^{\circ} \mathrm{C}$, obtaining AA from $0.1 \%$ to $0.36 \%$ without going through the atomization process.

5. All quartzite samples are in accordance with strength to bending, as European Standard EN 100, exceeding $27 \mathrm{MPa}$ (minimum voltage defined by the standard for porcelain stoneware production) at $1200^{\circ} \mathrm{C}$ sintering, showing that the use of quartzite residues in ceramic mass is presented as excellent potential for porcelain stoneware production.

\section{REFERENCES}

1. ABIROCHAS. Associação Brasileira Da Indústria De Rochas Ornamentais. Rochas Ornamentais no Século XXI. 2014. Disponível em: <http://www.abirochas.com.br/br/index.html>. Acesso em: 10 jan. 2014.

2. ABNT. Associação Brasileira de Normas Técnicas. NBR 13818 - Placas cerâmicas para revestimento - especificação e métodos de ensaios. Rio de Janeiro, RJ, 1997.

3. ANFACER. Associação Nacional dos Fabricantes de Cerâmicas para Revestimento. Revestimentos Cerâmicos do Brasil, 2013.

4. CASAGRANDE, M.C. Reaproveitamento de resíduos sólidos industriais: processamento e aplicações no setor cerâmico. Cerâmica Industrial, vol.13 (1/2), pp. 34-42, 2008.

5. MROLSD. Mineral Resources On-Line Spatial Data. Quartizite. 2013. 1f. Department of the Interior, U.S. Geological Survey, 2013. Disponível em: <http://mrdata.usgs.gov/geology/state/ sgmc-lith.php?text=quartzite>. Acesso em: 04 dez. 2013.

6. SEBRAE. Várzea: Cidade sem desempregados. Disponível em: <http://www.agenciasebrae.com. $\mathrm{br} /$ noticia. $\mathrm{kmf}$ ?canal=36\&cod=9686513\&indice=20 > . Acesso em: 10 jan. 2014.

7. SOUZA, A. P. F.; LIMA, A. A., GOPINATH, T. R. G.; NADLER, H. C. S. Uma abordagem técnica e ambiental sobre depósitos de quartzitos no estado da Paraíba. I SBRO/ II SRON, 2001, Salvador - BA.

8. VIEIRA, C. M. F.; MONTEIRO, S. N.; FILHO, J. D. Formulação de Massa de Revestimento Cerâmico com ArgilasPlásticas de Campos dos Goytacazes (RJ) e Tanguá (SP). Cerâmica Industrial. Novembro/Dezembro; 2001. 